\title{
Some Effects of a Rotational Grazing Treatment on Quan- tity and Quality of Available Forage and Amount of Ground Litter
}

\author{
R.K. HEITSCHMIDT, S.L. DOWHOWER, AND J.W. WALKER
}

\section{Abstract}

A 16-paddock, cell-designed, rotational grazing (RG) system was initiated in March 1981 to evaluate the effects of RG on various vegetation response variables and cow/calf production. This 20-month study was initiated in January 1983 to contrast herbage dynamics in the RG treatment to those in a yearlong continuously grazed treatment (MC). Rate of stocking in the RG treatment was $3.7 \mathrm{ha} / \mathrm{cow} /$ year as compared to a moderate rate of $5.9 \mathrm{ha} / \mathrm{cow} /$ year in the MC treatment. There was no difference between treatments in herbage growth dynamics. Total herbaceous standing crop, however, was greater in the MC treatment than the RG because of greater amounts of senesced forage. The resultant effect on forage quality, in terms of crude protein (CP) concentration and organic matter digestibility (OMD) was that they were generally greater in the RG than the MC treatment. Litter standing crop was also less in the RG than MC treatment although seasonal dynamies were similar. Results indicate differences between treatments were.caused primarily by differences in stocking rates and not grazing systems.

Key Words: crude protein, organic matter digestibility, cell grazing, continuous grazing

Interest in rotational grazing systems (RG) has increased dramatically in the U.S. during the past 10 years. Of particular interest has been the claim that proper implementation of a multi-paddock RG system will improve rangeland productivity in terms of livestock carrying capacity (Savory and Parsons 1980). This increase in carrying capacity has been attributed generally to substantial increases in quantity and quality of forage produced as a result of the positive effects of the physical impact of the grazing herd on the range ecosystem relative to plant growth and ecological succession. This claim was made, however, in the absence of any supportive scientific data. Thus, in 1981 we designed a series of studies to evaluate the effects of a RG treatment on quantity and quality of herbage produced and consumed, harvest efficiency, animal behavior, watershed condition, livestock performance (cow/calf), and economic profits. Four previous papers have quantified the effects of 2 livestock densities in a RG treatment on quantity (Heitschmidt et al. 1987a) and quality (Heitschmidt et al. 1987b) of forage produced, watershed condition (Pluhar et al. 1987), and density of cattle trails (Walker and Heitschmidt 1986). Our objective in this paper is to contrast differences between heavily stocked RG and moderately stocked yearlong continuously grazed (MC) treatments releative to quantity and quality of available forage and ground litter biomass. Subsequent papers will contrast differences relative to quantity and quality of forage consumed and various grazing behavioral patterns of mature cows.

\footnotetext{
Authors are associate professor, research associate and former research associate, Texas Agr. Exp. Sta., Box 1658, Vernon 76384.

Appreciation is expressed to the Swen R. Swenson Cattle Co. for providing the land, livestock and facilities for this study; the Texas Experimental Ranch Committee for providing financial assistance; Dr. M.M. Kothmann, Department of Range Science, Texas A\&M University, for qualitative analyses; and Dr. E.W. Richardson, Institute of Statistics, Texas A\&M University, College Station, for his assistance in data summarization and statistical analyses.

Report is published with approval of the Director, Texas Agr. Exp. Sta. as TA 21853.

Manuscript accepted 31 December 1986.
}

\section{Methods}

Study was conducted at the Texas Experimental Ranch located on the eastern edge of the Rolling Plains resource region $\left(99^{\circ} 14^{\prime} \mathrm{W}\right.$, $33^{\circ} 207$. Climate is continental, semiarid, and highly variable. Annual precipitation is bimodally distributed and averages 682 $\mathrm{mm}$. Peak precipitation months are May $(96 \mathrm{~mm})$ and September $(118 \mathrm{~mm})$. Average maximum daily temperatures range from $11.4^{\circ}$ $\mathrm{C}$ in January to $35.8^{\circ} \mathrm{C}$ in July. Average minimum daily temperatures range from $-2.4^{\circ} \mathrm{C}$ in January to $22.0^{\circ} \mathrm{C}$ in July. For a complete discussion of the study area see Heitschmidt et al. (1985).

The 465-ha, cell-designed RG treatment was initiated in March 1981. Initially the treatment consisted of 14 paddocks that averaged 33 ha in size. The treatment was originally stocked with 125 Hereford/Angus crossbred cows at a heavy rate of 3.7 ha/cow/ year. Rate of stocking was constant until June 1984 when it was reduced to $5.2 \mathrm{ha} / \mathrm{cow} /$ year because of drought. Rate of rotation was flexible and varied according to vegetation growth rates and the nutritional requirements of the cows. Days of rest between grazing periods ranged from about 30 to 65 .

Four permanent 0.5 -ha study areas were located in 3 adjacent paddocks in March 1981. Two plots were located in the center paddock ( $30 \mathrm{ha}$ ) and 1 each in the 2 adjacent 27 -ha paddocks. Study areas were located about two-thirds of the distance away from the cell center toward the back of the paddocks. Location of the 2 study areas in the central paddock was such that when the central paddock was subdivided into three 10-ha paddocks in March 1982, the 2 study areas were then located in different paddocks. All 4 areas were located within $400 \mathrm{~m}$ of each other. Based on desired rest periods, length of graze in the 4 paddocks during the study ranged from 18 hours to 2 days in the 10-ha paddocks and from 2 to 4 days in the 27-ha paddocks. Hereafter, the 10-ha paddocks are referred to as the RG-42 treatment and the 27-ha paddocks as the RG-14 treatment.

The MC treatment was a single, 248-ha pasture that had been stocked at a moderate rate since 1960 . Although $2 \mathrm{MC}$ pastures were available for study, only a single pasture was selected because of logistic and labor constraints. Another continuously grazed treatment stocked at a rate equal to the RG treatment was not initiated at the onset of this series of studies because: (1) earlier research had shown it was unlikely that such a treatment could be maintained for any extended period of time (Heitschmidt et al. 1983); (2) the financial risks associated with such a large scale endeavor were unacceptablc; and (3) yearlong grazing at a moderate rate of stocking is the most common grazing practice in this region. Thus, the MC treatment in this entire series of studies is a nonreplicated "control" treatment although the two, 0.25 -ha study plots located near the center of the pasture are treated statistically as replicates. Both range condition and range site composition in the single MC pasture were similar to that in the $R G$ treatment. Stocking rate in the MC pasture was a constant $5.9 \mathrm{ha} / \mathrm{cow} / \mathrm{year}$.

All 6 study areas (2 each in RG-14, RG-42, and $M C$ ) were located on nearly level upland sites on Nuvalde soils, a member of the fine-silty, mixed, thermic Typic Calciustolls. Range site classification is clay loam. Dominant herbaceous species were sideoats grama [Bouteloua curtipendula (Michx.) Torr.], Texas winter- 
grass (Stipa leucotricha Trin. and Rupr.), Japanese brome (Bromus japonicus) Thunb., and in some years annual broomweed (Xanthocephalum spp.). Other common grasses were buffalograss [Buchloe dactyloides (Nutt.) Engelm.], common curlymesquite [Hilaria belangeri (Steud.) Nash], red threeawn (Aristida longiseta Steud.), silver bluestem [ Bothriochloa saccharoides (Swartz) Rydb.], and tumblegrass [Schedonnardus paniculatus (Nutt.) Trel.]. The areas supported a light stand of honey mesquite (Prosopis glandulosa Torr. var. glandulosa).

\section{Vegetation Sampling}

Immediately before (within 1-3 days) and after (within 1-2 days) every grazing period from March 1981 to December 1984, the herbaceous vegetation in the RG treatment was clipped at ground level in ten, $0.25-\mathrm{m}^{2}$ quadrats/replicate. Vegetation in the $\mathrm{MC}$ treatment was sampled in a like manner but only on 7 dates: January, June, and September 1983; and January, March, May, and August 1984. These specific dates were selected because of the need for vegetation data for concurrent animal diet, intake, and behaviorial studies.

Herbage was clipped by the dominant species/species groups on all sample dates. Dominant species/species groups, hereafter referred to as species, and their designated codes were sideoats grama (Bocu), Texas wintergrass (Stle), annual grasses (Angr), other warm season grasses (Wsgr), annual broomweed (Xasp), and other forbs (Forb). Following drying $\left(60^{\circ} \mathrm{C}\right)$ and weighing, live/ dead ratios were estimated by hand separation of five subsamples of each species of each species from each treatment. Following harvest, ground litter in all quadrats were collected by hand and vacuum, floated in water to remove soil contamination, oven dried, and weighed. All herbage samples were ashed at $600^{\circ} \mathrm{C}$ for expression on an organic matter basis. Percentage crude protein (CP) was determined following standard A.O.A.C. (1970) procedures. Organic matter digestibility (OMD) was determined following the procedures of Van Soest and Wine (1967). Reference samples of known in vivo digestibility were analyzed in each batch run for standardization of OMD estimates. Forage quality analyses were limited to subsamples collected in the RG treatment because previous research (Heitschmidt et al. 1982b) had shown \%CP of live and dead tissue of a given species was unaffected by grazing treatment. Subsamples were combined by treatment (RG-14 and RG-42) and time (before and after grazing) prior to qualitative analyses.

\section{Data Summarization and Statistical Analyses}

Live organic matter standing crop was estimated for each species by multiplying total standing crop of each species by the percentage live estimate. Dead standing crop was then estimated by subtraction. Average CP and OMD percentages were calculated for each species by multiplying live and dead organic matter standing crop estimates by their respective \%CP and \%OMD values as determined in the laboratory, and dividing by the total standing crop for each species. Total organic matter standing crops were estimated by summing species. Average \%CP and \%OMD for total standing crop were estimated by summing $C P$ and $O M D$ standing crop estimates for each species and then dividing by the total organic matter standing crop.

All data were subjected to least squares analyses of variance. Because previous analyses indicated no difference between the RG-14 and RG-42 treatments relative to quantity (Heitschmidt et al. 1987a) and quality (Heitschmidt et al. 1987b) of standing crop, data from these treatments were combined. Furthermore, because the data from the MC treatment were the equivalent of the average of the before and after grazing estimates in the RG treatment in terms of forage availability, data from the $R G$ treatment were averaged across time (before vs. after grazing) within a sample date.

A split block model was utilized in the analyses of the organic matter standing crop data. Main effects were treatment (RG vs.
MC) and category (live vs. dead). The error term used to test for significant treatment and treatment by category effects was pastures within treatments. The residual was used to test for significant category effects. One-way analyses were used to test for differences between treatments in forage quality and litter biomass. Tukey's $Q$ tests were used for mean separations when appropriate. Unless otherwise noted, statistical significance is at $\boldsymbol{P}<0.10$. For a complete discussion of the study design, field sampling, and data summarization procedures, see Heitschmidt et al. (1987a, 1987b).

\section{Results}

Herbage growth dynamics were similar in both treatments during the 20-month study period (Fig. 1). Peak standing crop

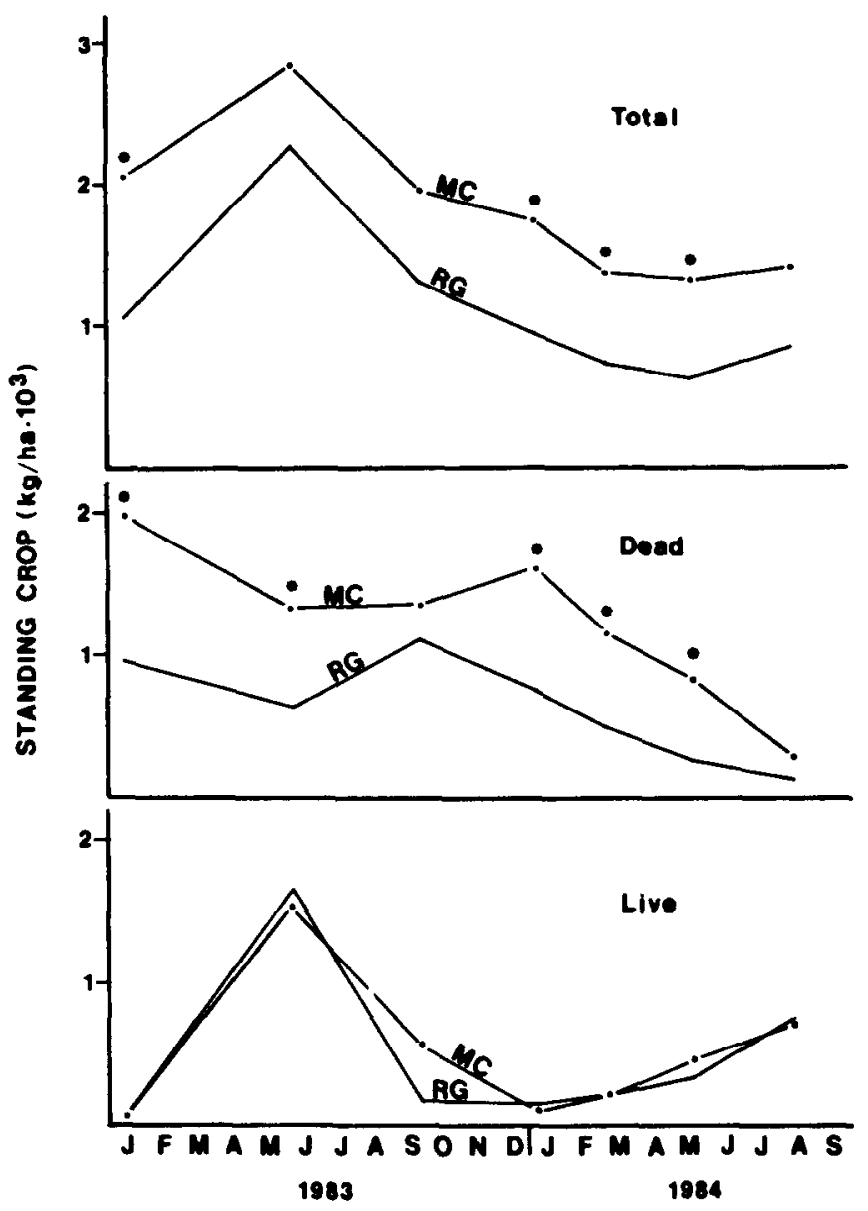

Fig. 1. Total dead and live herbaceous standing crop ( $\mathrm{kg} / \mathrm{ha}$ ) on clay loam range sites in the RG and MC treatments on 7 sample dates. Asterisks (*) identify dates when standing crops were significantly $(\mathrm{P}<0.10)$ different between treatments.

occurred in June 1983 and generally declined thereafter because of drought conditions during 1984 (Heitschmidt et al. 1987a). Total standing crop was generally greater in the MC than the RG treatment because of greater amounts of standing dead tissue (Fig. 1). There were 4 dates when total standing crop in the MC treatment was significantly greater than in the $R G$ treatment. In every instance this difference was because amount of dead biomass was significantly greater in the MC than the $R G$ treatment since amount of live biomass was never significantly different between treatments. The main effect of category was significant on 6 dates and reflected the effect of season.

Statistical analyses by individual species also showed differences between treatments were caused by greater amounts of dead biomass in the MC treatment. In the 42 analyses ( 7 dates $\times 6$ species) 
the main effect of treatment was never significant while the main effect of category was significant in 27 analyses. The category by treatment interaction effect was significant in 11 analyses indicating amounts of live and dead biomass differed between treatments. In 9 of these instances the amount of dead biomass in the MC treatment was significantly greater than the amount of dead biomass in the RG treatment. There were only 2 instances when amount of live biomass was significantly greater in the RG treatment than in the MC treatments (Bocu, May 1983; and Wsgr, August 1984) and only 2 instances when amount of live biomass was significantly greater in the MC treatment (Wsgr, September 1983; and Forb 1984).

Forage quality, in terms of $\mathrm{CP}$ and $\mathrm{OMD}$, was generally greater in the RG treatment than the MC (Fig. 2). This difference was
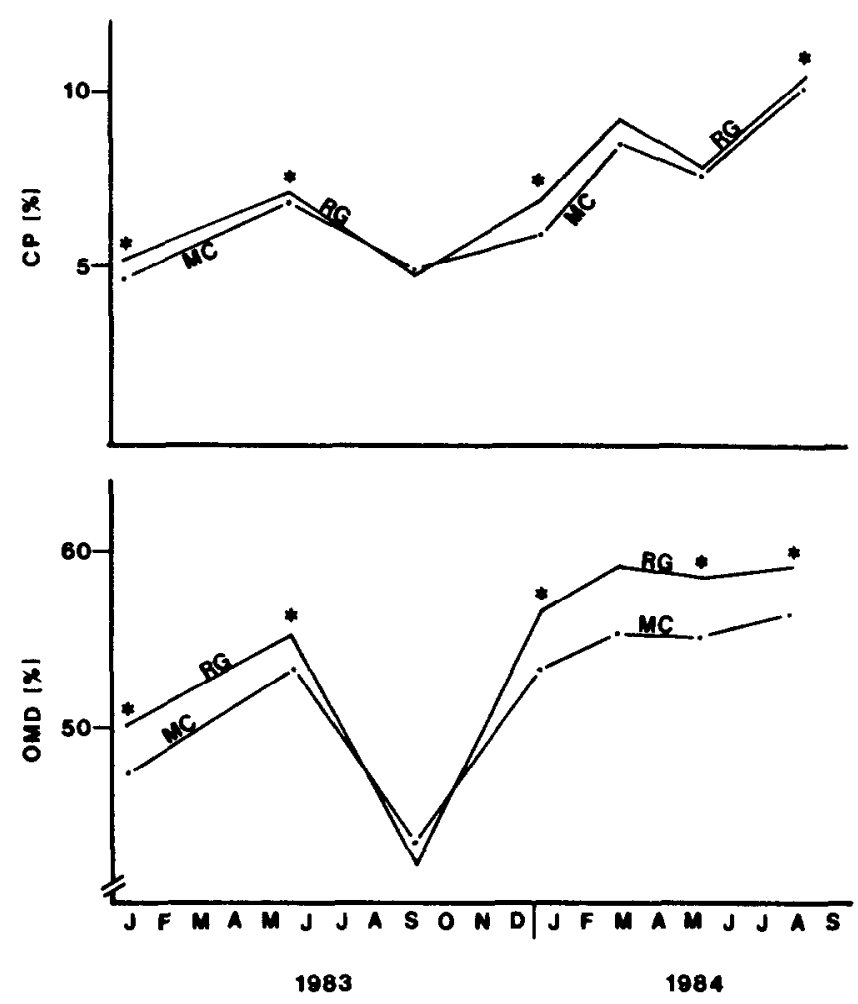

Fig. 2. Crude protein concentration (\%CP) and organic matter digestibility (\%OMD) of total herbaceous standing crop on clay loam range sites in the RG and MC treatments on 7 sample dates. Asterisks (*) identify dates when differences between treatments were significant $(\mathrm{P}<0.10)$.

caused by the presence of greater amounts of dead tissue in the MC treatment than in the RG treatment (Fig. 1), which tended to reduce the overall quality of the forage in the $\mathrm{MC}$ treatment (Heitschmidt et al. 1987b). The difference was not caused by greater amounts of live tissue in the RG treatment.

Litter biomass was generally greater in the MC than the RG treatment (Fig. 3), but it was only significantly greater on 2 dates. Variation in amounts of litter among sample dates was generally greater in the RG treatment probably because of greater physical impact of the cow herd. The results showed a strong relationship existed between quantity of herbage standing crop and litter biomass over time because herbage standing crop was also generally greater in the MC treatment than the RG (Fig. 1).

\section{Discussion}

The results of this study show that differences did occur between grazing treatments relative to quantity $(M C>R G)$ and quality $(\mathrm{MC}<\mathrm{RG})$ of available forage and litter biomas $(\mathrm{MC}>\mathrm{RG})$. Although we recognize that stocking rate and grazing system were

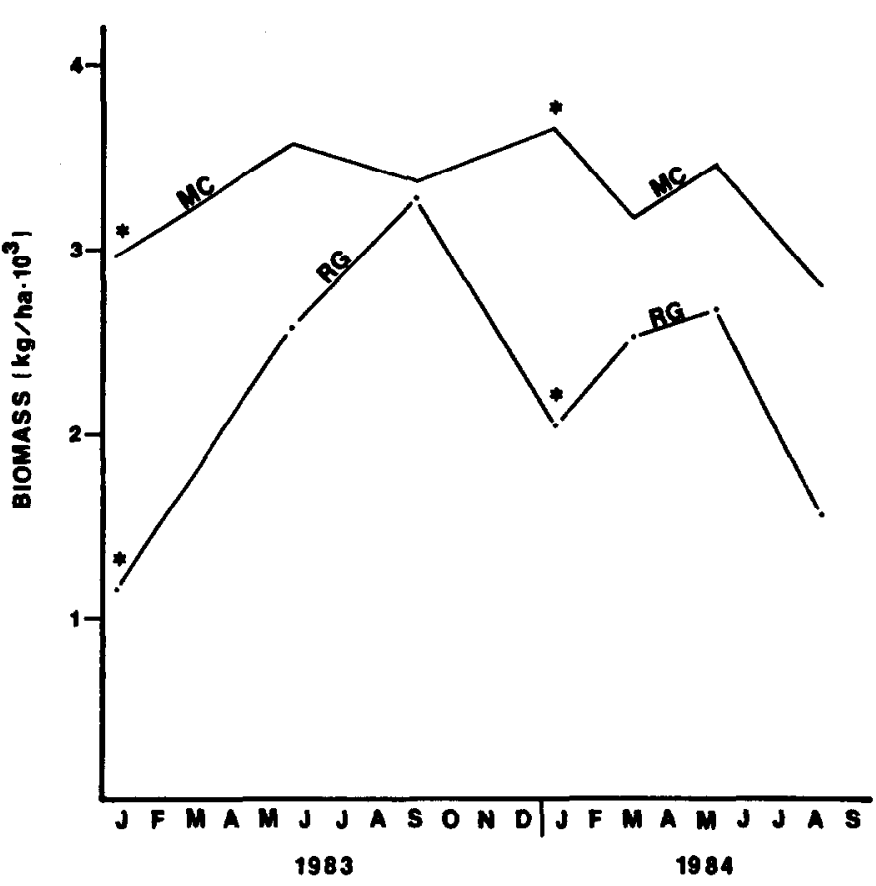

Fig. 3. Organic matter standing crop ( $\mathrm{kg} / \mathrm{ha}$ ) of ground litter on clay loam range sites in the $R G$ and $M C$ treatments on 7 sample dates. Asterisks (*) identify dates when litter biomass was significantly $(\mathrm{P}<0.10)$ different between treatments.

confounded in this study, we believe stocking rate was the principal factor that caused differences to occur between treatments. We believe a basic understanding of the biological and physical laws of nature as they pertain to the natality, growth, reproduction, and mortality of plants tends to support this general conclusion. The question, therefore, is not whether stocking rate was the principal factor or not, but rather how much were the differences in response between the 2 treatments altered as a function of grazing system? In other words, what is the magnitude of the stocking rate by grazing system interaction relative to RG and other grazing systems/ methods?

Quantitative yearlong grazing studies specifically designed to address stocking rate by RG system interactions do not exist for semiarid rangelands. However, there is sufficient evidence from studies conducted over a wide range of vegetation types and climatic conditions (Gammon 1978, 1984) to conclude that the interaction effects are small even if conditions are optimal (e.g., tame pasture, adequate rainfall, periods of rapid vegetation growth) for attaining a positive interaction effect (McMeekan and Walshe 1963, Conway 1963, Walker and Scott 1968, and Robinson and Simpson 1975). The lack of a positive interaction effect on semiarid rangelands is most likely related to the interaction effects of frequency and severity of defoliation of plants and subsequent plant growth. Although treading and excretion of waste products by grazing animals do have innumerable direct and indirect effects on grazed ecosystems relative to watershed condition (Blackburn et al. 1982) and nutrient cycling (Schimel et al. 1986), the magnitude of their effect is far less than that of defoliation (Curll and Wilkins 1983). Because frequency and severity of defoliation increase as a direct function of grazing intensity (Hodgson and Ollerenshaw 1969, Briske and Stuth 1982), regardless of grazing system (Gammon and Roberts 1978b, 1978c), it follows that unless herbage growth is enhanced in direct proportion to level of defoliation, herbage standing crop will decline as rate of stocking is increased. Studies suggesting an enhancement in the growth of individual plants following selective defoliation are certainly limited in number (Jameson 1963, McNaughton 1979, McNaughton 
et al. 1983), and in reality have minimal applicability to rangeland grazing environments in which biomass must be accumulated during the growing season for consumption during periods of either slow or no growth such as summer drought or winter. In support of these generalizations, Gammon and Roberts (1978d) found there were essentially no differences between continuously grazed and RG (simulated 6-paddock) treatments stocked at equivalent grazing intensities, relative to quantity and quality of available forage and litter biomass. The absence of any differences between treatments among these parameters was related to the absence of any major differences between treatments in grazing selectivity and frequency and severity of defoliation of individual tillers (Gammon and Roberts 1978a, 1978b, 1978c).

\section{Conclusions}

Although the results from this study are both regionally and range site specific, we believe they support a general conclusion that differences between grazing treatments were primarily caused by differences in stocking rate and not grazing system. Furthermore, based on the results of this study, our experiences over the past 6 years, and the results from other studies, we believe a small $(10-15 \%)$ increase in carrying capacity can generally be anticipated following establishment of properly managed RG system on extensively managed rangeland. We believe this increase, however, will be primarily the result of better livestock distribution rather than because of an enhancement in forage production. We also believe the results from this and other studies strongly support the specific conclusion that rotational-type grazing systems do not unequivocally eliminate the potential hazards commonly associated with excessive rates of stocking on rangelands.

\section{Literature Cited}

A.0.A.C. 1970. Official methods of analysis (11th ed.). Ass. Off. Agr. Chem. Washington, DC.

Blackburn, W.H., R.W. Knight, and M.K. Wood. 1982. Impact of grazing on watershed: A state of knowledge. Texas Agr. Exp. Sta. MP 1496.

Briske, D.D., and J.W. Stuth. 1982. Tiller defoliation in a moderate and heavy grazing regime. J. Range Manage. 35:511-514.

Curll, M.L., and R.L. Wilkins. 1983. The comparative effects of defoliation, treading and excreta on a Lolium perenne-Trifolium repens pasture grazed by sheep. J. Agr. Sci., Camb. 1:451-560.

Conway, A. 1963. Effect of grazing management on beef production. II. Comparison of three stocking rates under two systems of grazing. Irish J. Agr. Res. 2:243-257.

Gammon, D.M. 1978. A review of experiments comparing systems of grazing management on natural pastures. Proc. Grassl. Soc. S. Afr. 13:75-82.

Gammon, D.M. 1984. An appraisal of short duration grazing as a method of veld management. Zimbabwe Agr. J. 81:59-64.

Gammon, D.M., and B.R. Roberts. 1978a. Patterns of defoliation during continuous and rotational grazing of the Matopos sandveld of Rhodesia. 1. Selectivity of grazing. Rhod. J. Agr. Res. 16:117-131.

Gammon, D.M., and B.R. Roberts. 1978b. Patterns of defoliation during continuous and rotational grazing of the Matopos sandveld of Rhodesia. 2. Severity of defoliation. Rhod. J. Agr. Res. 16:133-145.
Gammon, D.M., and B.R. Roberts. 1978c. Patterns of defoliation during continuous and rotational grazing of the Matopos sand veld of Rhodesia. 3. Frequency of defoliation. Rhod. J. Agr. Res. 16:147-164.

Gammon, D.M., and B.R. Roberts. 1978d. Characteristics of herbage on offer during continuous and rotational grazing of the Matopos sandveld of Rhodesia. Rhod. J. Agr. Res. 16:3-22.

Heitschmidt, R.K., S.L. Dowhower, R.A. Gordon, and D.L. Price. 1985. Response of vegetation to livestock grazing at the Texas Experimental Ranch. Texas Agr. Exp. Sta. Bull. 1515.

Heitschmidt, R.K., S.L. Dowhower, and J.W. Walker. 1987a. 14- vs. 42-paddock rotational grazing: Aboveground biomass dynamics, forage production, and harvest efficiency. J. Range Manage. 40:216-223.

Heitschmidt, R.K., S.L. Dowhower, and J.W. Walker. 1987b. 14- vs. 42-paddock rotational grazing:- Forage quality. J. Range Manage. 40:315-317.

Heitschmidt, R.K., J.R. Frusure, D.L. Price, and L.R. Rittenhouse. 1982 . Short duration grazing at the Texas Experimental Ranch: Weight gains of growing heifers. J. Range Manage. 35:375-379.

Heitschmidt, R.K., R.A. Gordon, and J.S. Bluntzer. 1982b. Short duration grazing at the Texas Experimental Ranch: Effects on forage quality. J. Range Manage. 35:372-374.

Heitschmidt, R.K., A.B. Johnson, J.R. Frasure, and D.L. Price. 1983. Cow-calf and vegetation response to heavy rates of stocking at the Texas Experimental Ranch. Texas Agr. Exp. Sta. Bull. 1427.

Hodgson, J., and J.H. Ollerenshaw. 1969. The frequency and severity of defoliation of individual tillers in set-swards. J. Br. Grassl. Soc. 24:226-234.

Jameson, D.A. 1963. Responses of individual plants to harvest. Bot. Res. 29:532-594.

McMeekan, C.P., and M.M. Walshe. 1963. The inter-relationships of grazing method and stocking rate in the efficiency of pasture utilization by dairy cattle. J. Agr. Sci. Comb. 61:147-163.

MeNaughton, S.J. 1979. Grazing as an optimization process: Grassungulate relationships in the Serengeti. Amer. Natur. 113:691-702.

MeNaughton, S.J., L.L. Wallace, and M.B. Cughenour. 1983. Plant adaptation in an ecosystem context: Effects of defoliation, nitrogen, and water on growth of an African $C_{4}$ sedge. Ecology 64:307-318.

Pluhar, J.J., R.W. Knight, and R.K. Heitschmidt. 1987. Infiltration rates and sediment production as influencd by grazing systems in the Texas Rolling Plains. J. Range Manage. 40:240-243.

Robinson, G.G., and I.H. Simpson. 1975. The effects of stocking rate on animal production from continuous and rotational grazing systems. J. Brit. Grassl. Soc. 30:327-332.

Savory, A., and S.D. Parsons. 1980. The Savory grazing method. Rangelands 2:234-237.

Schimel, D.S., W.J. Parton, F.J. Adamsen, R.G. Woodmansee, R.I. Senft, and M.A.Stillwell. 1986. The role of cattle in the volatile loss of nitrogen from a shortgrass steppe. Biogeochemistry 1:39-52.

Van Soest, P.J., and R.H. Wine. 1967. Use of detergents in the analysis of fibrous feeds. IV. The determination of plant cell wall constituents. $J$. Ass. Off. Anal. Chem. 50:50.

Walker, B., and G.A. Scott. 1968. Grazing experiments at Ukiriguru, Tanzania. I. Comparisons of rotational and continuous grazing systems on natural pastures of hardpan soils. E. Afr. Agr. For. J. 34:224-234.

Walker, J.W., and R.K. Heitschmidt. 1986. Effect of various grazing systems on type and density of cattle trails. J. Range Manage. $39: 428-431$. 